〈症例報告〉

高歯者悪性リンパ腫の化学療法後寛解期に発症した食道狭窄の 1 例

\begin{tabular}{|c|c|c|}
\hline 太地 ${ }^{1)}$ & 尾崎 & 絵美1) \\
\hline 政志"1) & & 郁也 ${ }^{1)}$ \\
\hline
\end{tabular}

\begin{abstract}
要 約 症例は 75 歳, 女性. 2003 年 8 月下腿浮腫, 無尿を認め近医受診し, 水腎症および腹胿内リンパ節 腫大を指摘され, 当院泌尿器科に紹介され入院. 鼠径部リンパ節生検の結果, 悪性リンパ腫 (Non-Hodgkin, diffuse large B cell, stage IIA）と診断され当科に転科した。同年 9 月より R-CHOP 化学療法を 6 コース施 行され完全寛解となった. 2004 年 7 月中頃より嚥下障害が出現したため, 同年 8 月 16 日当科に再入院した. 食道透視および上部消化管内視鏡検査で中下部食道に潰瘍を伴う全周性の狭窄を認めた．表在リンパ節は触 知せず，全身 CT, Ga シンチ, 上部消化管内視鏡下生検でも明らかな悪性リンパ腫の再発や食道癌の所見 は認めなかった，LDH，可溶性 IL-2 レセプター, 各種腫瘍マーカーも正常範囲であった，以上より良性食 道狭窄の可能性が考えられたが，狭窄も高度で保存的治療は困難であり，また悪性疾患の可能性も完全には 否定できなかったため, 当院第 1 外科に転科し 9 月 21 日腹胿鏡下食道切除術および胃管再建術を施行した. 病理所見より食道潰瘍による瘕痕性狭窄と考えられた。悪性リンパ腫の化学療法後寛解期早期に発症し，鑑 別診断が困難であった良性食道狭窄の症例を経験したので報告する.
\end{abstract}

Key words : 食道狭窄, 化学療法, 逆流性食道炎, 脊椎圧迫骨折, 悪性リンパ腫

（日老医誌 $2006 ； 43 ： 531-535 ）$

\section{緒言}

高齢者に発症する食道狭窄の原因として食道癌をはじ めとする悪性腫瘍のほか, 逆流性食道炎, バレット食道, 酸・アルカリによる腐食性食道炎, 薬剤性などによる良 性食道狭窄などの疾患があげられている1”. バリウムに よる食道透視所見，上部消化管内視鏡検查などに加え， 発症までの臨床経過や病歴などがそれらの原因疾患の鑑 別に重要である．今回われわれは，悪性リンパ腫の化学 療法後寬解期早期に発症し，鑑別診断が困難であった良 性食道狭窄の症例を経験したので報告する.

\section{症例}

症例 : 75 歳, 女性.

主訴：嚥下困難.

既往歴：74 歳 悪性リンパ腫（Non-Hodgkin, diffuse large $B$ cell type).

家族歴：特記事項なし。

1) T. Azuma, E. Ozaki, Y. Yakushijin, M. Kohno, I. Sakai：愛媛大学医学部第一内科

2）K. Takada：愛媛大学医学部付属病院総合臨床研修 センター

受付日：2005.10.28, 採用日：2006.3.27
現病歴： 2003 年 8 月下腿浮腫, 無尿を認め近医を受 診し, 水腎症, 腹胿内および鼠径部リンパ節腫大を認め 当院泌尿器科に紹介され入院した，鼠径リンパ節生検の 結果，悪性リンパ腫（Non-Hodgkin， diffuse large B cell type, stage IIA）と診断され当科に転科し, 同年 9 月 よりリツキシマブ併用化学療法（R-CHOP 療法）を入院 および外来で 6 コース施行され完全寛解となった．以後 外来で経過観察されていたが 2004 年 7 月中頃より嚥下 障害が出現し，近医で上部消化管内視鏡施行され，高度 の食道狭窄を認めたため, 同年 8 月 16 日精査加療目的 で当科に再入院した。

入院時現症：身長 $136 \mathrm{~cm}$, 体重 $33.4 \mathrm{~kg}$, 体温 $37.0^{\circ} \mathrm{C}$, 意識清明, 血圧 $142 / 62 \mathrm{mmHg}$, 脈拍 78 /分整, 眼瞼 結 膜貧血なし, 眼球結膜黄染なし, 表在リンパ節触知せず, 肺正常肺胞音ラ音なし，心音純雑音聴取せず，腹部平坦 軟圧痛なし, 肝脾触知せず, 下肢軽度浮腫あり, 神経学 的所見異常なし，亀背を認める。

入院時検查成績 : 血液・生化学検查では軽度の筫血, Alb の低下を認める以外特に異常所見は認めず, 各種腫 瘍マーカー, 可溶性 IL-2 レセプターもすべて正常範囲 であった（Table 1).

便潜血は陰性. 上部消化管内視鏡検査では門歯列より 約 $25 \mathrm{~cm}$ の部位から肛門側に表面に潰瘍病変を伴う高度 
Table 1 Laboratory data on admission

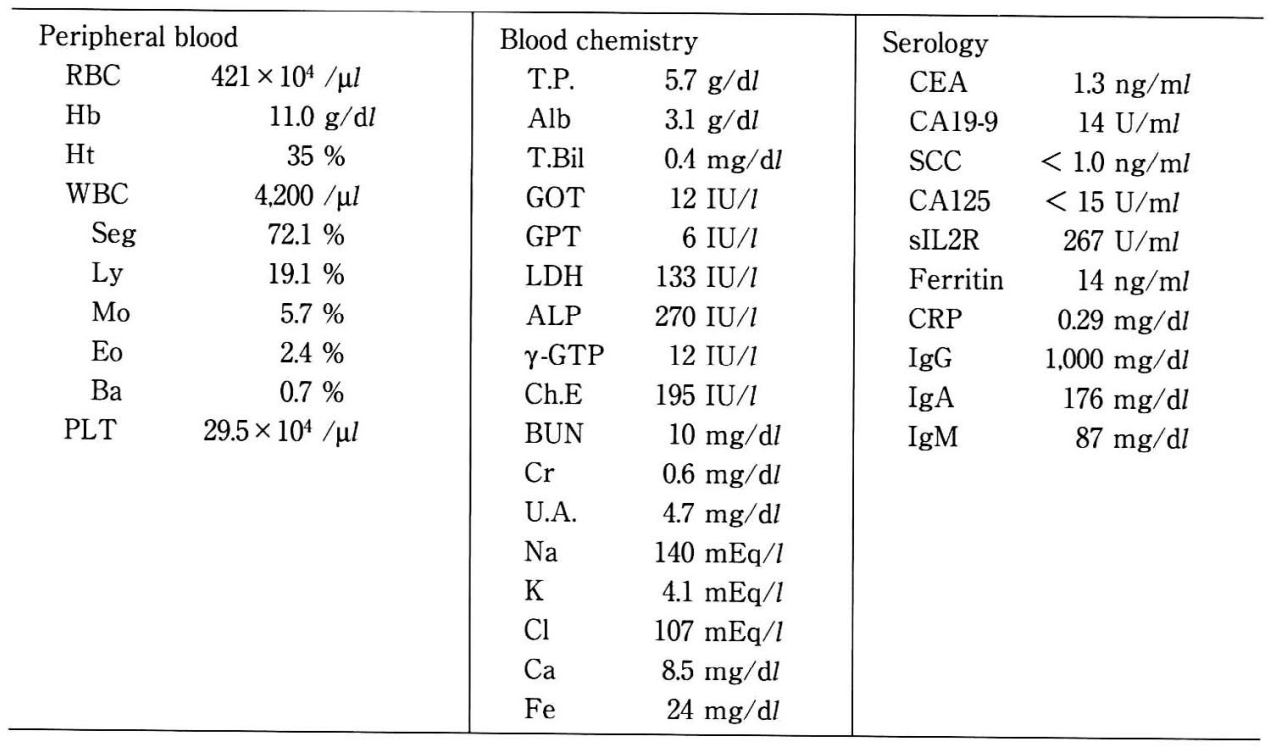

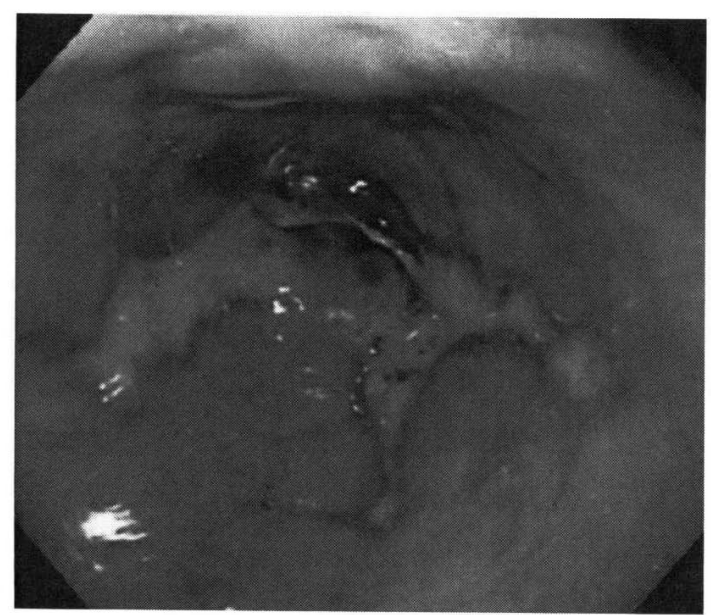

Fig. 1a The upper gastrointestinal endoscopy revealed esophageal stricture and ulcerative lesions on the mucosa of esophagus

の狭窄を認め,ルゴール染色では観察範讲には特に不染 域は認めなかった（Fig. 1). 潰瘍病変も含め数力所生検 を施行したが，組織所見はいずれも悪性リンパ腫や食道 癌などの悪性所見は認めず，非特異的な炎症像のみで あった，バリウムによる上部消化管造影検查では中下部 食道に約 $6 \mathrm{~cm}$ にわたり潰瘍病変を伴う高度の食道狭窄, 扔よび食道裂孔ヘルニアを認めた（Fig. 2)，胸部 CT で は食道壁の肥厚が疑われたが，他に異常所見はなく腫瘤 や縦隔リンパ節の腫大も認めなかった．腹部 CT および 全身 $\mathrm{Ga}$ シンチにても異常所見なく覀性リンパ腫の再発 を示唆する所見は認めなかった．脊椎 MRI では多発性 の脊椎圧迫骨折を認めた (Fig. 3).

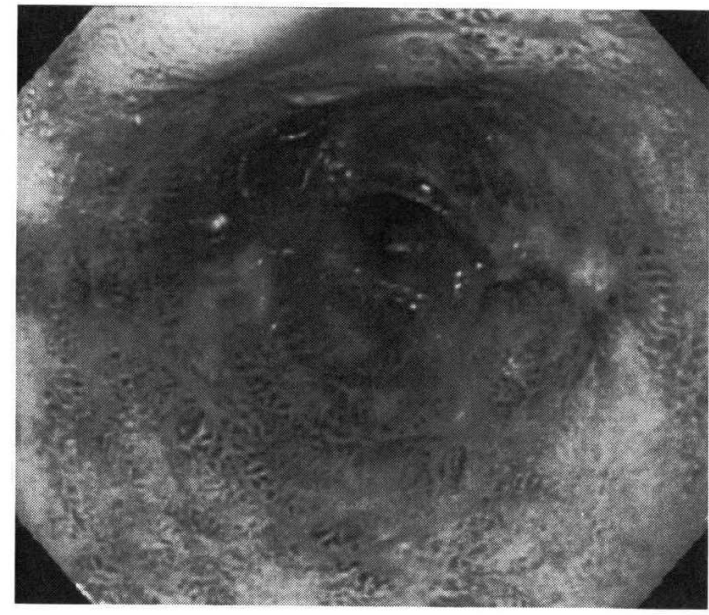

Fig. 1b Chromoendoscopy with Lugol's iodine solution did not demonstrate non-staining area on the mucosa of esophagus

入院後経過 : 食道狭窄のため嚥下困難は認めたが, 軟 飯および軟菜食の経口聣取は可能であった。これまでの 経過から胸やけなどの症状も認めず，原因となりうる 酸・アルカリの誤飲や薬片もなかったこと, 突然嚥下困 難で発症したことなどから食道癌や悪性リンパ腫の再燃 による食道浸潤を疑った。 しかし, 血液検査や各種困像 検査では明らかな悪性腫湯を示唆する所見は認めず，内 視鏡下生検でも悪性の所見は得られなかった．臨床所見 および MRI で脊椎生迫骨折による亀背を認め, バリウ ム検査でも高位の食道裂孔ヘルニアを認めたため, 逆流 性食道炎による良性食道狭窄を最も疑った，食道狭窄が 高度でありプロトンポンプインヒビター（以下 PPI と 


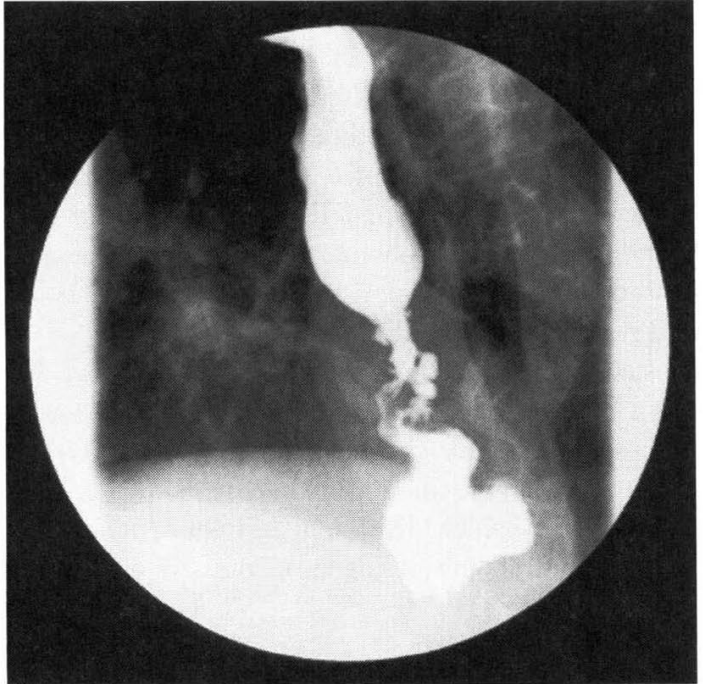

Fig. 2 A barium esophagogram revealed severe esophageal stricture with niches and hiatus hernia

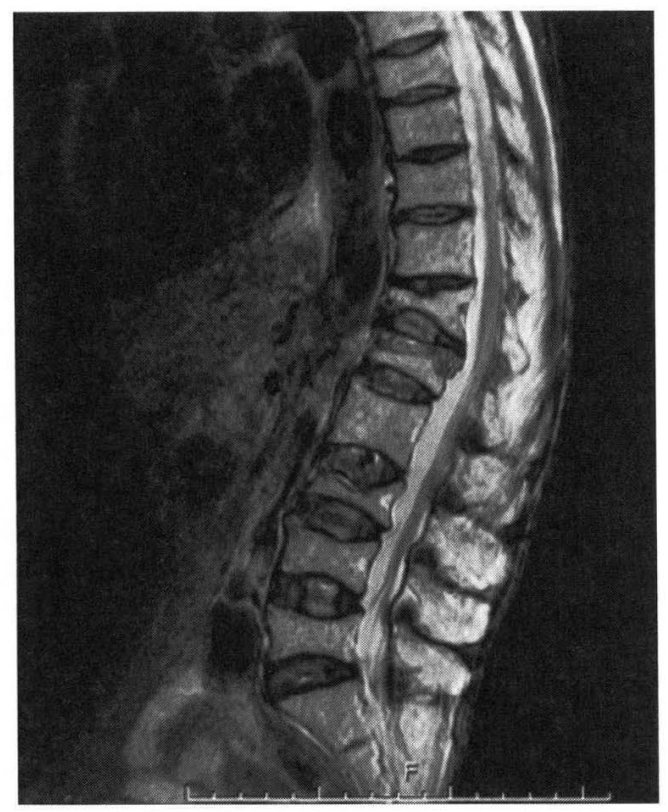

Fig. 3 Magnetic resonance imaging showed multiple compression fractures of the spine

略す）内服だけでは治癒困難であり，内視鏡下拡張術な ども考虑したが, 内視鏡下治療にともなう穿孔などの合 併症の危険性, さらには悪性リンパ腫も完全には否定で きなかったことなどにより本人も外科的手術を希望し, 2004 年 9 月 21 日当院第 1 外科にて腹哚鏡下食道切除術 および胃管再建術を施行した. 術後経過は良好で 9 月 29 日より経口攝取を再開し，特に合併症は認めず 10 月 12 日退院した。病理組織所見は中下部食道に潰瘍, 肉芽組 織, 筋層内に強い線維化を認め, 逆流性食道炎および潰

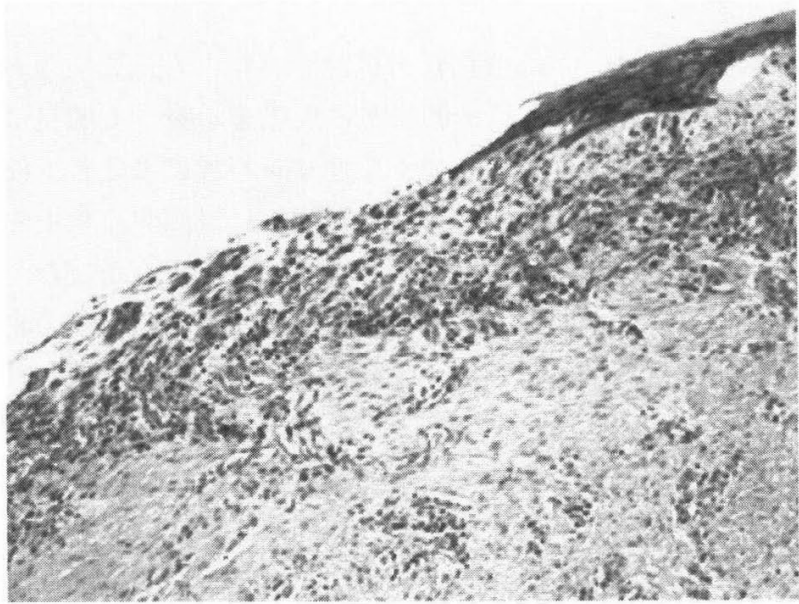

Fig. 4 The histological examine showed lymphoid infiltrations with ulceration on the mucosa, and fibrosis in the propria muscularis of esophagus

Malignant cells were not found in the specimen (HEstaining, $\times 100$ ).

瘍による廄痕性狭窄と考えられ，悪性所見は認めなかっ た（Fig. 4). なお，入院時認められていた貧血は治療後 約 1 年経過した現在 $\mathrm{RBC} 459 \times 10^{4} / \mu l, \mathrm{Hb} 12.3 \mathrm{~g} / \mathrm{d} l$, Ht $39.9 \%$ と回復しており, やはり食道炎による上部消 化管出血により鉄欠乏性督血を来していたものと考えら れた。

\section{考察}

本症例では，悪性リンパ腫治療後に発症した食道狭窄 であり，鑑別診断に苦慮した．消化管に病変を伴う悪性 リンパ腫は比較的多いが, その多くは胃および小腸であ り，食道浸潤は非常にまれである ${ }^{2)-7)}$. 一方, 悪性リン パ腫の治療後に続発性食道狭窄の発症も報告されてい る.おもに縦隔リンパ節に対する放射線照射がその原因 であるが, 化学療法による薬剂性狭窄も指摘されてい $ろ^{8) ~(0)}$. Doxorubicin は悪性リンパ腫の標準治療法であ る CHOP 療法の 1 薬剤であるが, doxorubicin 投与によ り食道狭窄をきたした報告例もある ${ }^{11}$. その他 5fluorouracil , vinblastine, actinomycin , methotrexate, cytosine arabinoside な゙の薬殽との関 連も報告されている(2)-14)。これらの抗癌剤は細胞周期に おいて細胞傷害性が生じるため, 細胞增殖の早い消化管 の上皮細胞は影響を強く受けやすく，粘膜のびらんから 食道炎に進展し, 潰瘍・壊死を来し食道狭窄を発症する と考えられる だけでなく，頻回の嘔吐に伴う食道炎，真菌やウイルス などの感染症による食道潰瘍なども食道狭窄の原因とな 


\section{りうる.}

本症例では，上部消化管内視鏡，バリウム造影検査お よび CT 検査では, 積極的に悪性疾患を示唆する所見は 認めなかったが, 前述の如く悪性リンパ腫による食道浸 潤の可能性や食道癌, 特に食道粘膜下に浸潤する食道癌 の報告もあり，やはり悪性疾患の否定はできなかった。 ただしバリウムによる上部消化管造影検査で, 高度の食 道裂孔ヘルニアを認め, 逆流性食道炎の存在が示唆され たこと,さらに, 脊椎圧迫骨折は食道裂孔ヘルニアおよ び逆流性食道炎の危険因子であり ${ }^{15} 16$, 本症例でも臨床 所見および画像所見より春椎圧迫骨折による龟背をみと めており, 胸やけ等の症状は認めなかったが, やはり逆 流性食道炎の存在が示唆され, 良性食道狭窄が強く疑わ れた。 また，さらに本症例にも doxorubicin 等を使用し ており, 薬剤性の食道狭窄も加味された可能性もある.

また，これまで悪性リンパ腫治療後に食道狭窄を来し た症例は, 化学療法および放射線照射治療後比較的長期 間経過観察しえた症例で報告されており，そのため若年 者が多いが, 近年支持療法の進歩に伴い高齢者にも多剂 併用化学療法を行う症例も多くなっており, 脊椎圧迫骨 折や逆流性食道炎などの食道狭窄の危険因子を有する場 合も多いことが考えられ，今後高齢者に化学療法施行す る場合，食道狭窄には注意しておく必要があると考えら れた，さらにはGutpa らの報告では食道狭窄の悪性お よび良性の鑑別にはバリウムを用いた上部消化管造影が 有用であるとされており ${ }^{171}$, 本症例においてもその有用 性が示唆された.

高龄者悪性リンパ腫の化学療法後寞解期に発症した食 道狭窄の 1 例を経験した。粘膜下を浸潤する食道癌や悪 性リンパ腫の食道再発などの悪性疾患と逆流性食道炎に よる良性食道狭窄の鑑別が困難であったが，バリウムに よる消化管造影検查や脊椎圧迫骨折などの臨床所見がそ の鑑別に非常に有用であった．脊椎圧迫骨折を併発して いる高齢者に対し, 胸やけなどの臨床症状がなくても, できるだけ定期的にバリウム造影検査や内視鏡検査を行 い, 早期からの PPI 内服治療が必要であると考えられ た.

本論文の要旨は第 16 回日本老年医学会四国地方会 (平 成 17 年 2 月 5 日, 高松市) で発表した.

\section{文献}

1) Monda LA : Diagnosis and treatment of esophageal strictures. Radiol Technol $1999 ; 70: 361-372$.
2) Crump M, Gospodarowicz M, Shepherd FA: Lymphoma of the gastrointestinal tract. Semin Oncol $1999 ; 26: 324^{-}$ 337.

3) Bierman PJ : Gastrointestinal lymphoma. Curr Treat Options Oncol $2003 ; 4: 421-430$.

4) Weeratunge CN, Bolivar HH, Anstead GM, Lu DH: Primary esophageal lymphoma: a diagnostic challenge in acquired immunodeficiency syndrome-two case reports and review. South Med J $2004 ; 97: 383-387$.

5) Hosaka S, Nakamura N, Akamatsu T, Fujisawa T, Ogiwara $\mathrm{Y}$, Kiyosawa K, et al. : A case of primary low grade mucosa associated lymphoid tissue (MALT) lymphoma of the oesophagus. Gut $2002 ; 51: 281-284$.

6) Gupta NM, Goenka MK, Jindal A, Behera A, Vaiphei K : Primary lymphoma of the esophagus. J Clin Gastroenterol $1996 ; 23: 203-206$.

7) 住 昌彦, 高久智生, 井口具隆, 石井裕子, 片桐智子, 田内哲三ほか：食道原発び慢性大細胞型 $\mathrm{B}$ 細胞リンパ 腫. 臨床血液 $2004 ; 45: 1067-1069$.

8) Haddy TB, Adde MA, McCalla J, Domanski MJ, Datiles M 3rd, Meehan SC, et al. : Late effects in long-term survivors of high-grade non-Hodgkin's lymphomas. J Clin Oncol 1998; $16: 2070-2079$.

9) Ellenhorn JD, Lambroza A, Lindsley KL, LaQuaglia MP : Treatment-related esophageal stricture in pediatric patients with cancer. Cancer 1993; 71:4084-4090.

10）矢田健一郎, 山田 治, 岩戸康治, 許 泰一, 大柣剛已, 中西秀和ほか：化学療法後に急速に食道狭窄を来した急 性骨髄性白血病。臨床血液 $2002 ; 43: 41-43$.

11) Newburger PE, Cassady JR, Jaffe $\mathrm{N}$ : Esophagitis due to adriamycin and radiation therapy for childhood malignancy. Cancer $1978 ; 42:$ 417-423.

12) Karnak I, Senocak ME, Buyukpamukcu N : Esophageal stricture encountered during treatment of acute leukemia. J Pediatr Gastroenterol Nutr $2001 ; 32: 100-102$.

13) Slee GR, Wagner SM, McCullough FS: Odynophagia in patients with malignant disorders. Cancer 1985;55: 2877-2879.

14) Dahms BB, Greco MA, Strandjord SE, Rothstein FC: Barrett's esophagus in three children after antileukemia chemotherapy. Cancer $1987 ; 60: 2896-2900$.

15) Yamaguchi $T$, Sugimoto $T$, Yamada $H$, Kanzawa $M$, Yano S, Yamauchi M, et al.: The presence and severity of vertebral fractures is associated with the presence of esophageal hiatal hernia in postmenopausal women. Osteoporos Int $2002 ; 13: 331-336$.

16) Yamaguchi $T$, Sugimoto $T$, Yamrauchi M, Matsumori $Y$, Tsutsumi M, Chihara $\mathrm{K}$ : Multiple vertebral fractures are associated with refractory reflux esophagitis in postmenopausal women. J Bone Miner Metab $2005 ; 23: 36^{-}$ 40.

17) Gupta S, Levine MS, Rubesin SE, Katzka DA, Laufer I: Usefulness of barium studies for differentiating benign and malignant strictures of the esophagus. AJR Am J Roentgenol $2003 ; 180: 737-744$. 


\title{
Esophageal stricture following complete remission after chemotherapy for malignant lymphoma in an elderly patient
}

\author{
Taichi Azuma", Emi Ozaki", Yoshihiro Yakushijin" ${ }^{1)}$, Masashi Kohno", Ikuya Sakai" and Kiyonori Takada ${ }^{21}$
}

\begin{abstract}
A 75-year-old woman was given a diagnosis of malignant lymphoma (non-Hodgkin, diffuse large B cell type, stage IIA) at our hospital on August 2003. She received six courses of rituximab-based chemotherapy (R-CHOP regimen) and then she achieved complete remission. On August 16, 2004, she was readmitted in our hospital for difficulty in swallowing. Upper gastrointestinal endoscopy reveled esophageal stricture and an ulcerative lesion on the esophageal mucosa. The X-ray examination of the upper gastrointestinal tract reveled a severe esophageal stricture with niches and hiatus hernia. No malignancy was seen on CT scanning, gallium radioisotope scanning and histological examination of biopsy specimens with the upper gastrointestinal endoscopy. The physical examination showed gibbosity, and MR imaging showed multiple compression spined fractures. Finally, we diagnosed benign esophageal stricture with reflux esophagitis. She underwent laparoscopic partial esophagectomy in September 21, 2004, and the postoperative course was satisfactory. The pathological findings showed benign esophageal stricture caused by esophagitis. We report here a case of esophageal stricture following complete remission after chemotherapy for malignant lymphoma in an elderly patient.
\end{abstract}

Key words: Esophageal stricture, Chemotherapy, Reflux esophagitis, Compression fracture, Malignant lymphoma (Jpn J Geriat 2006; 43: 531-535)

1) The First Department of Internal Medicine, Ehime University School of Medicine

2) The General Clinical Training Center, Ehime University Hospital 